\title{
The expected role of railways in the economic development of Saudi Arabia
}

\author{
M. Aldagheiri \\ Department of Geography, Qassim University, Saudi Arabia
}

\begin{abstract}
The national economic diversification is considered a strategic goal for the Saudi Arabian government in most economic sectors away from the oil sector (e.g. Minerals, Agriculture, and Manufacturing). The development of these sectors has led to a high demand for transportation infrastructure, the provision of which has become a necessity. The transportation infrastructure affects most aspects of regional economic development, because most economic activities either depend on or use transportation means in the transport of products. Moreover, transportation means affect regional productivity by connecting different regions to each other and allowing the exchange of goods and services to occur among them. Additionally, it is considered a key component in business efficiency in the level and ease of access it provides to customers, markets, materials and workers. Therefore, to provide information about the ability of the existing transportation infrastructure to contribute to any economic activity, it is necessary to identify and evaluate the level of the existence of the transportation infrastructure in Saudi Arabia. This paper aims to evaluate the railways as a one of the important infrastructural systems.
\end{abstract}

Keywords: railways, transportation infrastructure, Saudi Arabia.

\section{Introduction}

Transportation systems, including railways, are considered an essential feature of all modern economies. Yeser [1] stated that transportation was considered for a long time to be the most important factor in regional, economic and social development. Transportation has an important role in increasing production, reducing travel times, increasing employment and improving accessibility. Furthermore, it plays an important role in reducing regional disparities and in 
improving the competitiveness of regions, by facilitating trade, the movement of labour, and economies of scale. The relationship between transportation infrastructure and economic development has been the focus of increasing analysis, discussion and interest during the past decade (Weiss [2], Felloni et al [3], Weiss and Figura [4]). The importance of transportation infrastructure to economic growth has been recognized for a long time. There is no doubt that investment in transportation systems (e.g. roads, ports and railways) stimulated economic development in North America in the 19th century. Roads and railroads allowed the United States to expand from states hugging the coast of the Atlantic Ocean to all the land between the Atlantic and Pacific (Francois [5]). In addition, transportation infrastructure has expanded the range over which goods can be marketed. Although there is very little empirical evidence to this effect, it is generally believed that the U.S. government's massive investment in transportation infrastructure development in the 19th century led to the significant growth registered by the country's economy during that period (Gillen [6]).

According to Norton [7] the historical review of the evolution of the transport network relies on an examination of the interaction between the development of the transport system and economic development. In the broadest sense it includes factors such as population growth and human activities, which have an impact on the landscape, influencing the evolution of transportation, and where the road network plays a significant role in facilitating all activities related to economic development. Robinson and Bamford [4] stated that the road network is made up of single roads that link together two or more points, or centres, of movement. It may therefore be regarded as a set of inter-connected roadways along which movement takes place. Different modes of transportation form prominent landscape features and indeed roads, railway tracks, waterways and electricity structures form imposing features on the landscape and in well-populated, industrial and urban areas there is usually a dense pattern of transportation lines.

\section{The importance of study}

The national economic diversification is considered a strategic goal for the Saudi Arabian government in most of economic sectors away from the oil sector (e.g. Minerals, Agriculture, and Manufacturing). The development of these sectors has led to a high demand for transportation infrastructure, the provision of which has become a necessity. The transportation infrastructure affects most aspects of the regional economic development, because most economic activities either depend on or use transportation means in the transport of products. Moreover, transportation means affect regional productivity by connecting different regions to each other and allowing the exchange of goods and services to occur among them. Additionally, they are considered a key component in business efficiency in the level and ease of access they provide to customers, markets, materials and workers. Therefore, to provide information about the ability of the existing transportation infrastructure to contribute to any economic activity, it is necessary to identify and evaluate the level of the existence of the transportation 
infrastructure in the Saudi Arabia. This paper aims to evaluate the railways as a one of important infrastructural systems.

\section{The railways system in Saudi Arabia}

Saudi Arabia is a large country, similar in size to Western Europe, and it is among the 25 largest economies in the world and the largest in the Arab world. But the country has a very small railway network which consists of a 449 kilometre passenger line linking Riyadh with the Gulf port of Dammam, and a 556 kilometre freight line which takes a more circuitous route between these two cities via Harad. The railways remain the least developed means of transportation in the Kingdom. The railways have been only a minor element in the country's transportation system, and were re-established in the early 1950s after a fourdecade hiatus. The Ottoman Turks built the first railroad on the peninsula, the Hejaz Railway linking Damascus with Madinah. Parts of this railroad were destroyed in World War I and the line was abandoned, especially that in Saudi Arabia. This section presents three stages of development for the railway network: firstly, the Hejaz Railway (old network); secondly, the existing railway network and finally, the expansion projects for the railway network.

\subsection{The Hejaz Railway}

The Hejaz Railway is considered to be the first railway in the Arabian Peninsula and ran between Damascus and Madinah. It was proposed to continue the railway to Makkah, but this section was never constructed. The construction of this railway started in 1900 and the railway reached Madinah in 1908. The construction, maintenance and security of this railway all presented enormous difficulties, and was mainly undertaken by 5,000 Turkish soldiers. Additionally, variations in the terrain itself made construction difficult, as the ground was very soft and sandy in places and rock solid in others. Water scarcity was the norm, but occasional torrential rainstorms caused flash floods, washing away bridges and banks and causing the railway to collapse (Landau [8], Al-Degn [9], Ziadh [10]).

Ostensibly, this railway was built to facilitate pilgrimages to the Muslims' holy places in Arabia but in fact also to strengthen Ottoman control over the most distant provinces of the empire. On 1 September 1908 the railway was officially opened, and was transporting 30,000 pilgrims a year by 1912 . Business boomed, and by 1914 the annual load had soared to 300,000 passengers. Not only were pilgrims transported to Madinah, but the Turkish army began to use the railway as its chief mode of transport for troops and supplies. During the First World War this railway was severely damaged. There was no direct intention to destroy the railway at this time; the main aim was simply to cripple it in order to impede the advance of the Turkish army. From the First World War until recent time, several attempts were made to revive this railway, but the scheme proved too difficult and too expensive. In addition, the expansion in road transport and air traffic in the 1970s and 1980s led to the cessation of these attempts (Ochsenwald [11], Tourret [12]). 


\subsection{The existing railway network}

Information from the Saudi Railway Organization (SRO) indicates that the idea of constructing a railway line in Saudi Arabia after the Hejaz Railway was first introduced in the mid-forties, when the need was felt for a port on the eastern sea-shore of the Kingdom to handle goods dispatched to the Aramco Petroleum Company. Such goods had to be conveyed inland from the port to the warehouses of Dhahran. This idea was presented to the late King Abdel Aziz Al Saud, who gave his assent to the project and instructed that the line should extend up to Riyadh, because Riyadh had been chosen as the government capital, and the need arose to link the capital with the economic areas in the east and the holy places in the west. Also, the position of Riyadh, which is closer to the east than the west, and the attraction of economic prosperity, encouraged the government to link Riyadh with Dammam by railway (Aldagheiri [13]).

Based on SRO [14] the construction work commenced in October 1947, and in October 1951 the railway line was officially inaugurated by the late King Abdel Aziz Al Saud. At first, Aramco ran the railway line but it was subsequently entrusted to the Ministry of Finance, at which time it was known as the Railway Department. The government later created the railway authority as a public corporation organization having a legal status with rights and duties just as a natural person. The name of this organization was the Saudi Government Railroad Organization (SRO). The SRO is responsible for rail transport in the Kingdom and is an autonomous agency headed by a President who is responsible for the policies and the day-to-day activities of the railways. He is supported by a Vice President. The SRO is controlled by a Board of Directors and chaired by the Minister of Transportation. There have been several development projects undertaken by the SRO, some of which are as follows:

- $\quad$ Construction of a direct railway line from Dammam to Riyadh with a total length of 499 kilometres.

- $\quad$ Construction of 3 modern passenger stations in Dammam, Hofuf and Riyadh.

- $\quad$ Establishment of a fully-equipped central maintenance workshop at Dammam.

- Construction, inauguration and operation of a dry port in Riyadh, which may be regarded as one of the most important achievements of the corporation. The availability of this service in Riyadh has greatly facilitated import of goods from abroad and clearance by customs directly to the importers in Riyadh (see Map 1) SRO [15].

Although the railway had a significant effect on the transport of goods and passengers between Riyadh and Dammam, the connection of Dammam with Riyadh by paved road in 1961 led to a considerable decline in goods and passengers carried by rail. In 1960 for example, the amount of goods transported from Dammam to Riyadh was 721,000 tonnes, but by 1961 this had already decreased to 671,000 tonnes, i.e. about 7.5 per cent fall. In 1962 this had 
decreased further to 650,000 tonnes. The number of passengers was also affected, decreasing from 98,000 in 1960 to 27,000 in 1962, a fall of 72.5 per cent. In addition, by the early 1970's, the railway system had reached an unsatisfactory position owing to, firstly, the decay of the infrastructure, secondly, the age and inefficiency of the rolling stock and thirdly, income and expenditure were out of balance and operating efficiency was continuously declining $\mathrm{Al}$ Metair [16].

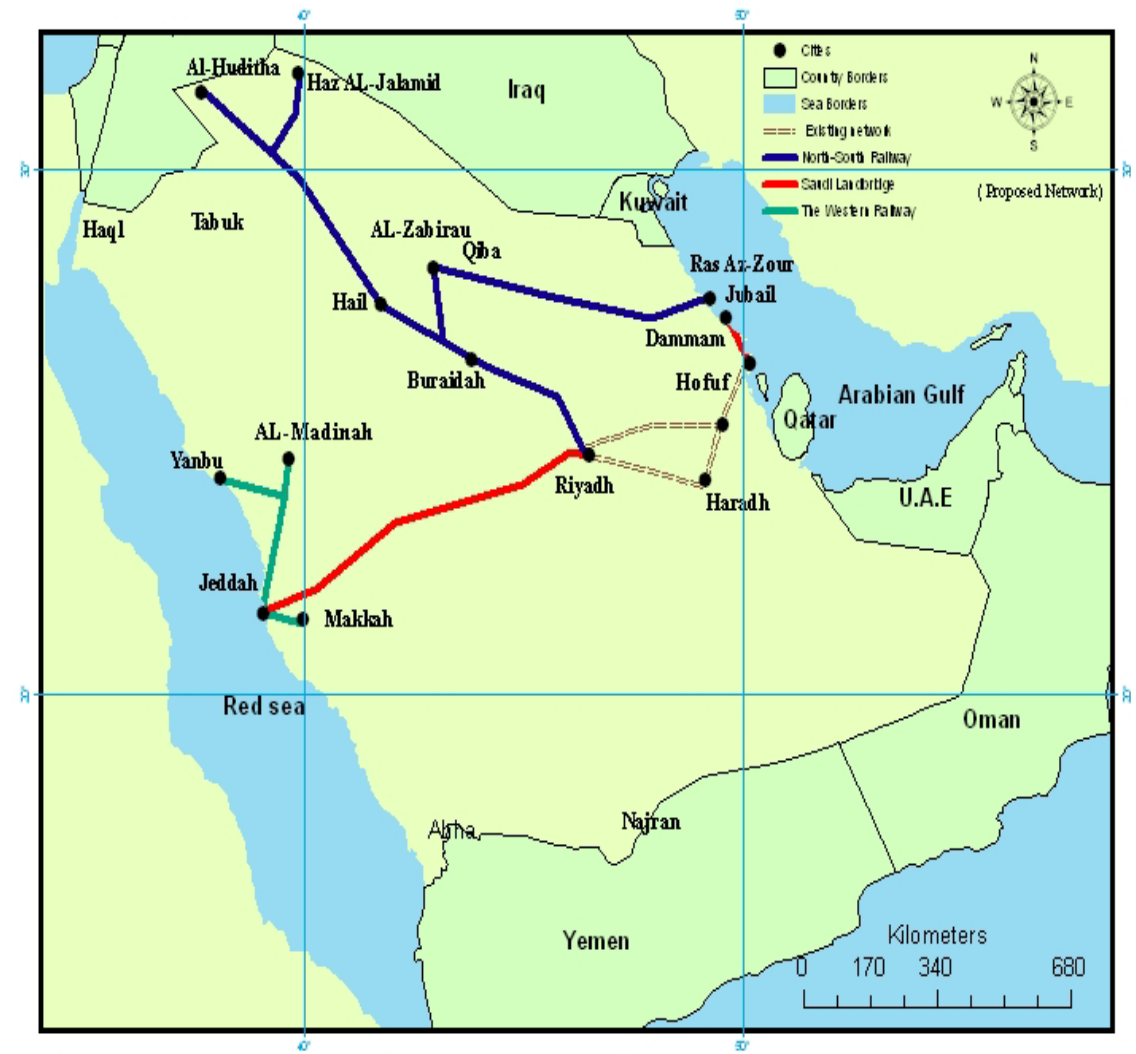

Figure 1: Existing and expansion railways network in Saudi Arabia. Source: Saudi Railways Organization (SRO) [14].

At the beginning of the 1980s and 1990s the SRO developed the railway system: both railway lines and the dry port. The official inauguration of Riyadh Dry Port took place on May 1981, at a time when the state of the economy was on the upswing and the route between Dammam and Riyadh witnessed very heavy traffic. In this context, the idea of a dry port at Riyadh was born, since a direct railway service to Riyadh would relieve the pressure on Dammam seaport. The number of imported containers received annually at Riyadh Dry Port increased considerably since more and more traders turned to the services provided by the dry port. This was due to the quality of services offered at 
advantageous prices and the ease and speed of delivery. Also, statistical information shows that the number of containers handled at Riyadh Dry Port since its inception in 1980 has increased more than seven-fold. For example, in 1980-1981, the number of standard containers which were handled was 21,000 and in 2003-2004, it was more than 141,405.

According to the SRO, the dry port has some significant benefits such as;

a) In handling and transporting cargos, whether in the form of containers, motor-cars, equipment or general merchandise, the dry port offers to its customers a speedy and efficient service.

b) The port can efficiently handle containers of different sizes and volumes, whether wholly or partly loaded.

c) The port authority is subject to liability for the safety of all kinds of goods consigned on its trains, including containers, motor-vehicles, equipment and general goods, from the time they are loaded on the train at Dammam, and until they are received by their owners at Riyadh.

d) The dry port at Riyadh has an advanced combination of specialized facilities, such as warehouses - cranes and other lifting gear devices various types of equipment - shadings - sufficient open space - etc. These facilities enable the Port to handle more than 200,000 standard containers per year.

e) Goods earmarked for export are received by the Port authority for dispatch to the sea port at Dammam. The Port authority is committed to follow-up the consignment until it is loaded on board the ship within the agreed period of time.

f) As noted previously, one of the benefits for traders is the speed and efficiency of handling of consignments at very competitive prices.

\subsection{The expansion projects}

As is known all over the world, railway networks are effective in moving large volumes of bulk commodities over long distances and according to regular schedules and when compared to other means of transport can often be cheaper. Furthermore, they are safe and efficient in use of fuel and are responsible for less environmental pollution than some other forms of transport. The Saudi Arabia government has long had an ambition to expand its rather modest railway, which currently links Riyadh via two railway lines to the port of Dammam. There are three big projects planned by which the dream finally looks set to become a reality. The Supreme Economic Council has approved the implementation plans for three railway projects, which will be under the direction of the Saudi Railways Organization.

The three railway projects are:

1. The Saudi Landbridge: this will involve building a new 950 kilometres line from the capital, Riyadh, west to the Red Sea port of Jeddah, and a 115 kilometre line from Dammam north along the Gulf coast to Jubail; the existing Riyadh-Dammam railway will also be upgraded. 
2. The Western Railway: 750 kilometres of new lines from Jeddah southeast to Makkah, and northeast to Madinah and Yanbu, and

3. The North-South Railway: a 1300 kilometre mineral railway running north from Riyadh to Hazm Al-Jalamid.

\section{The Saudi Landbridge}

This section starts by quoting Dr Jobarah Al-Suraisry, Saudi Arabia's Minister of Transport and chairman of SRO: "The time is right to bring the many advantages of rail transport to Saudi Arabia and this can only be achieved by extending the rail network to the main centres of population and industry. The landbridge project represents the cornerstone of our expansion plan. It will be one the largest BOT (build, operate, transfer) projects ever undertaken in the Middle East and is a key initiative in the railway expansion programme approved by the Kingdom's Supreme Economic Council" (Briginshaw [17]). Therefore, the Saudi Landbridge will transform the existing rail network in the Kingdom of Saudi Arabia into a world-class freight and passenger rail link across the country. It will have the capability to move large quantities of cargo over long distances at competitive rates and will offer safe and comfortable overland passenger transport. In addition, it will transform the Kingdom's existing network into one of the world's most important strategic freight links connecting the port cities of Jeddah, Dammam and Jubail via Riyadh's inland dry port. The delivery time for containers tracked between Dammam and Jeddah will be less than 48 hours compared to up to eight days journey by sea around Ras al Mandab from the Red Sea to the Arabian Gulf (Khmash [18], Jackson [19]).

The Saudi Landbridge will connect the port cities of Jeddah, Dammam and Jubail and will pass through the capital city Riyadh and serve its dry port (see Map 1). The project will involve:

- Construction of 950 kilometres of new line between Riyadh and Jeddah.

- Construction of 115 kilometres of new line between Dammam and Jubail.

- Upgrade of the existing railway link between Riyadh and Dammam, including connection to the new Riyadh-Jeddah and Dammam-Jubail lines.

- The integration of the new lines with the upgraded existing railway and with the ports at Jeddah, Dammam and Jubail and Riyadh Dry Port (and the expansion, operation and management of the Dry Port).

- The operation of freight transport on the new and existing lines (including procuring additional rolling stock) and (until the award of a separate passenger concession) passenger transport on the existing lines.

- The maintenance of the new and existing lines (Hughes [20]).

The Saudi Arabia government granted concessions to the private sector for the construction and operation of the Saudi Landbridge via a Build Operate Transfer (BOT) contract. This is considered to be one of the largest BOT schemes ever undertaken in the region. 


\section{The Western Railway}

There is a huge demand for travel between Jeddah and Makkah (about 80 kilometres) and Jeddah and Madinah (about 420 kilometres). Makkah, with a population of 1.6 million, is within commuting distance of Jeddah. Of the 16 million people that travel between the two cities a year, 7 million are commuters. Another 5 million are visitors, 2 million are Hajj pilgrims, and 2.5 million are Ramadan visitors. Madinah has nearly 1 million inhabitants and has 3 million visitors a year. Therefore, the purpose of the western railway project is to cater to the requirements of passengers, predominantly religious pilgrims and commuters, wishing to travel between Makkah, Jeddah and Madinah. In order to meet these requirements, the Government of KSA plans to develop a new railway infrastructure consisting of a high-speed line linking the three cities with six new stations. Moreover, the project will provide a safe, fast, reliable and comfortable mode of transport for Umrah visitors and Hajj Pilgrims travelling to Makkah and Madinah via Jeddah. This project will involve:

1) Construction of a new line between Jeddah and Makkah.

2) Construction of a new line between Jeddah and Madinah.

3) Construction of a spur from the Jeddah-Madinah line to Yanbu (see Map 1).

According to the SRO [21], the proposed western railway network will transport millions of passengers every year on state-of-the-art high speed railway infrastructure. At first, it is expected about 20 million travellers per year will travel by train between Jeddah and Makkah, but this number is expected to grow to 30 million by 2020. The traffic between Jeddah and Madinah is estimated at 3 million in year one, increasing to 4.5 million by 2030 . The KSA will grant concessions to the private sector for the construction and operation of the MMRL via a Design, Build, Operate and Transfer (DBOT) contract.

The stations for this line will be located in strategic locations in each of the cities: Makkah, Jeddah and Madinah. There will also be a connection to the city of Rabigh to serve daily commuters to the King Abdullah Economic City. The stations will be located as follows:

- Jeddah City Centre: a station will be a part of the Municipality development plan for a multimodal transport station near Jeddah's old airport.

- Jeddah International Airport: a station in the new airport for the convenience of travellers from the airport into the city centre, Makkah and Madinah avoiding heavy road traffic. A second station in the Hajj terminal for Hajj and Umrah performers during high season.

- On the outskirts of Makkah to serve daily commuters travelling to universities and businesses.

- Close to the Haram, about four hundred metres from the Haramto to help Umrah performers to complete their mission and leave the city to continue other business. 
- Madinah station will be located about three kilometres from the Prophet's Mosque (Masjid Alnabawi).

- Rabigh station will be located near the city to serve employees and businessmen expected to travel to and from the newly developing King Abdullah Economic City.

\section{The North-South Railway}

The reason for building the north-south railway can be shown from an interview with the President of Saudi Railways Organization Dr Al-Yahya, who said "In the past it was the government's strategy to expand highways and roads. But things have changed. The Saudi demography and the size of the economy have changed, and diversification has become government policy. All these developments have dictated a fresh look at the railway sector" Cited in SRO's official website. The North-South railway project was conceived to serve two major ore bodies located in the north of the Kingdom. These now form the core traffic for a new network extending north of Riyadh. This line would also support projected industrial development in Saudi Arabia north of Riyadh, particularly around the urban centres of Buraidah, Majma'h, and Hail (see Map 1).

Saudi Arabia is home to some of the largest phosphate deposits in the world, so this project is a major investment in infrastructure by the Saudi Arabia government and will conclude with the construction of 1,800 kilometres of standard gauge single railway track including the existing railway network. Its primary objective will be to connect bauxite and phosphate mines at Az Zubairah and Al Jalamid to processing facilities located at the Arabian Gulf port of Ras Azur. Ras Azur is located approximately 200 kilometres to the north of Dammam. In addition to mineral traffic, the North-South railway project will serve passengers and freight traffic from Riyadh to Al-Hudaitha. The railroad network will run from Al-Hudaitha near the border with Jordan and continue all the way to Riyadh via Al-Jouf, Al-Zabira (Hail), Qassim and Sudair. A railroad spur will connect Hazm Al-Jalamid and Al-Zubairah (Hail) to Ras Az-Zour (southeastern part) along the railroad to Jubail.

\section{Conclusion}

The development of transportation infrastructure plays an important role in the economic development of a country and, therefore, the kilometre-age of railways existing in a country is often used as an index to assess the extent of its development. The proper development of a rail network not only reduces the cost of transportation both in terms of money and time, but also helps in the integration of various regions within the country and better understanding of neighbouring countries at the international level. The transportation infrastructure in Saudi Arabia contributed to the development of the country by bringing in direct benefits from its role in the development of some tradable sectors such as agriculture, industry and commerce. Also, transportation infrastructure can contribute direct benefits in the mining field and the minerals sector generally which is considering as future strategy for the economic 
development of Saudi Arabia. In general this contribution to the transportation infrastructure in the minerals sector may be considered as a progressive government policy to assist the tradable sectors to diversify away from the hydrocarbon sector. The role of transportation in this case is considered a very positive one.

Economic growth and the development of transportation infrastructure are closely related. One reason for this positive relationship is that transportation infrastructure influences regional productivity through the facilitation of the efficient movement of goods and labour used in production. The reduction in time and effort required to produce goods translates directly into increased regional productivity. In vast countries like the Kingdom of Saudi Arabia, where the main population centres are not only scattered all over the country but are also separated by deserts, sand dunes, valleys and mountains, reliable means of transportation are essential. Therefore, the government of Saudi Arabia appreciates the importance of this sector and a lot has been achieved during the last few decades. At the present time, the Saudi Arabia government has started to expand its modest railway, by means of three large projects: the Landbridge, the Western Railway and the North-South Railway. Additionally, Saudi Arabia enjoys a number of stations on these large projects that are equipped with the most modern equipment, machinery, installations and facilities for the handling of cargo. The Kingdom today not only enjoys an effective transportation system but also provides opportunities for choice between different transport modes. Thus, the growing complexity of the transport system is increasingly reflected in the competition beginning to emerge between transport modes.

\section{References}

[1] Yeser, M., Transport and Development in the Yemen Arab Republic, Ph.D thesis, University of Wales, 1990.

[2] Felloni, F, Wahl, T, and Wandschneider, P., Evidence of the Effect of Infrastructure on Agricultural Production and Productivity: Implications for China, Chinese Agriculture and the WTO, Proceedings of WCC-101, Seattle, Washington, 1999.

[3] Weiss, M. and Figura, P., A Provisional Typology of Highway Economic Development Projects, US DOT, Highway Administration: Washington DC, pp. 115-119, 2003.

[4] Robinson, H. and Bamford, C., Geography of transport, Macdonald \& Evans, Plymouth (Devon), 1978.

[5] Francois, F., 21st Century Linkage between Transportation and the Economy, Transportation Consultant: Transportation and Economic Development, Transportation Research Board (TRB) Committee on Transportation and Economic Development (A1A06), 2002.

[6] Gillen, D.W., Transportation infrastructure and economic development: A review of recent literature, Logistics and Transportation Review, 32, pp. 39-62, 1996.

[7] Norton, W., Historical analysis in geography, Longman, London, 1984. 
[8] Landau, J., The Hejaz Railway and Muslim Pilgrimage, A case of Othman Political Propaganda, Wayne State University Press, Detroit, 1971.

[9] Al-Degn, A., Alhamidiah's Hejaz Railway, documentary study, First edition, Alazhr University (In Arabic), 1985.

[10] Ziadh, N., The Hejaz Railway, Transport and Communications Magazine, No. 25, p. 68-69 (In Arabic), 2000.

[11] Ochsenwald, W., The Hijaz Railroad, The University Press of Virginia, USA, 1980.

[12] Tourret, R., Hedjaz Railway, Abingdon, J. B. Shears and Sons Ltd, 1989.

[13] Al-dagheiri, M, The Analysis of the Efficiency of Transport Road Network in the Al-Qassim Region, Saudi Arabia: A Geographical Study, MSc Dissertation, University of Leicester, UK, 2004.

[14] SRO, Saudi Railways Organization, The railroad of Saudi Arabia, Saudi Railways Organization Press, Saudi Arabia (In Arabic), 2000.

[15] SRO, Saudi Railways Organization, The Railroad from Hijaz Railways to Future's Railways, Transport and Communications Magazine, No. 10, p. 18-21 (In Arabic), 1999.

[16] Al-Metair, A. N., Impact of socio-economic change on Saudi urban transportation, Eastern Region, Ph.D thesis, University of Durham, UK, 1987.

[17] Briginshaw, D., Saudis launch rail Landbridge project, International Railway Journal, V. 45, issue 3, p.18, 2005.

[18] Khmash, H., New Railway Project Links between Dammam and Jeddah, Al- Qafilah Magazine, No. 2, V. 54 (In Arabic), 2005.

[19] Jackson, C., Saudi Landbridge ready to launch, Railway Gazette:http://www.railwaygazette.com/Articles/2005/03/01/1425/Saudi+L andbridge+ready+to+launch.html, 2005.

[20] Hughes, M., Saudi expansion plans attract "substantial interest”, Railway Gazette:http://www.railwaygazette.com/Articles/2004/03/01/1947/Saudi+e xpansion+plans+attract+'substantial+interest'.html, 2004.

[21] SRO, Saudi Railways Organization, The Railways - Vision and Challenges, Saudi Railways Organization Press, Saudi Arabia (In Arabic), 2005. 